Resource and Research Unit, University of Toronto, $180 \mathrm{p}$. [in English].

6. Greenwood, M. (2006). Children are a gift to us: Aboriginal-specific Early childhood Programs and Services in Canada. Canadian Journal of Native Education, 29(1), pp. 12-28. [in English].

7. Greenwood, M., de Leeuw, S., \& Ngaroimata Fraser T. (2007). Aboriginal Children and Early Childhood Development and Education in Canada: Linking the Past and Present to the Future. Canadian Journal of Native Education, 30(1), pp. 5-18. [in English].

8. Handbook of Best Practices in Aboriginal Early Childhood Programs. (2003). BC Aboriginal Child Care Society, 140 p. [in English].

9. Krishnan, V. (2010). Early Childhood Development: A Conceptual Model. Early Child Development Mapping Project, Alberta, 17 p. [in English].
10. Learn Canada 2020. Joint Declaration of Provincial and Territorial Ministers of Education. (2008). Retrieved from: http://www.cmec.ca/Publications/. [in English].

11. Native Women's Association of Canada. Retrieved from: http://www.nwac.ca/aboriginal-head-start. [in English].

12. Procher, L., \& Howe, N. (2000). Early Childhood Care and Education in Canada - UBC Press: Vancouver, 315 p. [in English].

13. Public Health Agency of Canada. Retrieved from: http://www.phac-aspc.gc.ca. [in English].

14. Statistics Canada. Retrieved from: http:// www.statcan.gc.ca/eng/start. [in English].

15. The State of Aboriginal Learning in Canada: A Holistic Approach to Measuring Success. (2009). Canadian Council On Learning, 78 p. [in English].

Стаття надійшла до редакції 17.04.2018

УДК 37.017

DOI:

Вікторія Яковлєва, доктор педагогічних наук, професор кафедри педагогіки та методики технологічної освіти

ДВНЗ “Криворізький Державний педагогічний університет”

Дійсний член міжнародної Академії безпеки життєдіяльності, м. Київ Дійсний член міжнародної Академії культури безпеки, екологї̈ та здоров'я, м. Київ Почесний член Свропейської асоиіаиїї з безпеки, Польщча, м. Краків

\title{
СПЕЦИФІКА ВИХОВАННЯ ПОЗИТИВНОГО СТАВЛЕННЯ ДО ПРАЦІ ПІДЛІТКІВ ЗАГАЛЬНООСВІТНІХ ІНТЕРНАТНИХ ЗАКЛАДІВ ТА ФОРМИ ЇЇ ОРГАНІЗАЦЇ̈ У ПОЗАУРОЧНИЙ ЧАС
}

У статті розкрито специфіку процесу виховання позитивного ставлення підлітків загальноосвітніх інтернатних закладів до праиі, обтрунтовано педагогічну доцільність здійснення изього процесу у позаурочній діяльності, проаналізовані основні напрями позаурочної діяльності, визначені найбільш ефективні форми виховання позитивного ставлення до прачі підлітків у позаурочний час.

Ключові слова: загальноосвітні школи-інтернати; підлітки шкіл-інтернатів; позитивне ставлення до праці; трудова діяльність; позаурочна діяльність; гурткова робота.

Jim. 7.

Victoriya Yakovlyeva, Doctor of Sciences (Pedagogy), Associate Professor of the Pedagogics, Theory and Methods of Technological Education Department State Higher Educational Institution "Kryvyi Rih State Pedagogical University" Active Member of International Academy of Life Safety, Kyiv Active Member of International Academy of Safety Culture, Ecology and Health, Kyiv Honorary Member of Europran Association of Safety, Poland, Krakow

\section{THE SPECIFICS OF EDUCATING THE POSITIVE ATTITUDE TO WORK OF TEENAGERS OF GENERAL EDUCATIONAL BOARDING SCHOOLS AND FORMS OF LABORACTIVITY DURING AFTER LESSONS}

The article analyzes the new social problems posed by modern society in general educational boarding schools, in particular, the tasks connected with the future work activity of their pupils, Social order for general boarding schools is to form a new system of values based on folk morals in the younger generation. The core of such a system is humanistic education, which aims to cultivate humanity, sensitivity, benevolence and national dignity. Labor activity is one of the important components of this process. The peculiarities of the pupils' contingent of these institutions that influence on the content and forms of the organization of labor activity, the specifics of the process are revealed the raising of the positive attitude of adolescents of general educational institutions to work. 


\section{СПЕЦИФІКА ВИХОВАННЯПОЗИТИВНОГО СТАВЛЕННЯ ДО ПРАЦІПДЛТТКІВ ЗАГАЛЬНООСВІТНІХ ІНТЕРНАТНИХ ЗАКЛАДІВ ТА ФОРМИ П̈Ӧ ОРГАНІЗАЦІї У ПОЗАУРОЧНИЙ ЧАС}

The general educational boarding schools are institutions that according to the content of education are identical to ordinary educational schools, that is, in their activities they are guided by the same tasks as mass schools.

However, because their pupils' contingent, in their majority, in terms of physical and mental development, the levels of education and studying are somewhat different from the pupils' community of traditional general schools, the content and forms of the process of raising a positive attitude to work have certain characteristics. Therefore, the subject of our study in the article is the specifics of the process of raising the positive attitudes of adolescents in general educational boarding schools to work and forms of organization after lesson.

The pedagogical feasibility of this process in the activities after lessons is substantiated and analyzed the main directions of activities after lessons, identified the most effective forms of education of a positive attitude to the work of activities after lessons.

Keywords: the general educational boarding schools; the teenagers of boarding schools; the positive attitude to work; labor activity; the activities after lessons; a group work.

$\Pi$ остановка проблеми. Сучасне суспільство поставило закладам інтернатного типу нове соціальне завдання - сформувати вільну особистість, здатну захищати і відстоювати свою власну позицію, керуючись як національними, так і загальнолюдськими принципами і нормами життєдіяльності. Соціальне замовлення загальноосвітнім школам-інтернатам зводиться до того, щоб “сформувати в молодого покоління нову систему цінностей, що грунтується на народній моралі. Стрижнем такої системи $є$ гуманістичне виховання, яке має за мету виховання людяності, чуйності, доброзичливості та національної гідності” [5].

Трудова діяльність учнів $\epsilon$ однією із важливих складових у даномупроцесі. Ми підтримуємо думку тих науковців, які вважають, що почугтя поваги до праці пов' язує дитину духовними нитками обов' язку з іншими людьми - спочаткуз близькими, а потім 3 усіма чесними співвітчизниками. 3 почугтя поваги до праці, з думки про те, що праця - творець щастя, народжується той стан повинності, без якого немислимо собі уявити елементарну моральну культурулюдини, ії відповідальність за своє майбугнє $[4 ; 6]$.

Враховуючи дану проблему, сучасні загальноосвітні заклади (зокрема, інтернатні) ставлять перед собою завдання “виховання в молоді усвідомленого позитивного ставлення до праці, розуміння іiї соціальної значущості, розвитку потреби в трудовій активності, ініціативності, схильності до підприємництва, розуміння економічних законів і проблем суспільства та засобів їх розв'язання, готовності до творчої діяльності, конкурентоспроможності й самореалізації за умов ринкових відносин, сформувати працелюбність як базову якість особистості”[2].

Загальноосвітні школи-інтернати - це заклади, які за змістом навчання тотожні звичайним навчально-виховним школам, тобто у своїй діяльності вони керуються тими самими завданнями, що і масові школи.
Однак, оскільки, їх учнівський контингент у своїй більшості за фізичним і розумовим розвитком, рівнем вихованості і освіченості дещо відрізняються від учнівського загалу традиційних загальноосвітніх шкіл, то і зміст, і форми процесу виховання позитивного ставлення до праці мають певні особливості. Тому предметом нашого дослідження у статті $є$ специфіка процесу виховання позитивного ставлення підлітків загальноосвітніх інтернатних закладів до праці та форм іiї організації у позаурочний час.

Аналіз останніх досліджень і публікацій. Значнакількість науковців(А.А. Алад’їн,С.Я.Харченко I.О. Фурманов, Н.В. Фурманова та ін.) приділяють певну увагу тому факту, що психічний розвиток вихованців загальноосвітніх інтернатних закладів дуже своєрідний. Дослідники виявили наявність руйнівних тенденцій у їх загальному розвитку, зумовлені, передусім, особливостями соціально-економічних труднощів, що виникли у суспільстві і в окремих родинах.

Тому вони вважають, що трудове навчання та трудове виховання учнів $є$ одним із ефективних шляхів організації гуманістичного виховання (зокрема, коли йдеться про школярів, які мають труднощі у спілкуванні). Особливої уваги заслуговують праці Я.С. Кепші (виховання у підлітків творчого ставлення до праці у позаурочний час); С.В. Лісової (педагогічні основи виховання культури праці учнів основної школи у процесі навчання і виховання); А.Б. Рацул (суспільно корисна праця як фактор морального виховання учнів загальноосвітніх шкіл-інтернатів); В.С. Римаренко (формування у школярів трудових умінь у процесі виробничої праці) тощо.

Виклад основного матеріалу. Відомо, що низька якість навчання і виховання учнів у загальноосвітніх школах-інтернатах досить часто залежить від певних труднощів, 3 якими стикаються учні в ході спілкування з однолітками і дорослими, а також змісту діяльності, до якої вони залучені.

Саме тому, предметом нашого дослідження 


\section{СПЕЦИФІКАВИХОВАННЯПОЗИТИВНОГО СТАВЛЕННЯ ДО ПРАЦІПДЛТКІВ ЗАГАЛЬНООСВІТНІХ ІНТЕРНАТНИХЗАКЛАДІВ ТА ФОРМИ ЇӦ ОРГАНІЗАЦІЇ У ПОЗАУРОЧНИЙ ЧАС}

стала специфіка процесу виховання позитивного ставлення підлітків загальноосвітніх інтернатних закладів до праці та форм іii організації у позаурочний час.

Позаурочна робота повинна пропонувати школяру дуже різні способи задоволення його потреб та інтересів, утворювати імунітет до “всеїдності” у мистецтві, у виборі книг, занять, розваг, допомагати визначити його нахили, пережити успіх в активній діяльності, яку він обирає.

Позаурочна діяльність є сполучною ланкою між школою та життям. Сфера ㄲï за останні роки значно розширилась, зміст збагатився за рахунок зв'язку із трудовими, виробничими колективами, громадськими організаціями. Досвід інтелектуальнодуховної, суспільно корисної, естетично-художньої діяльності став джерелом усвідомлення та дієвості знань, отриманих учнями із природно уповільненим темпом розвитку. На думку Л.В. Канішевської: “Добровільний характер позаурочної діяльності сприяє вибірковій участі у ній вихованців шкіл-інтернатів, прагненню їх до задоволення своїх інтересів та потреб і накладає відповідальність на педагогічну організацію позаурочної діяльності учнів (ретельний відбір змісту будь-якого заняття, використання нових, невідомих учням форм і методів, що підвищують інтерес)" [3].

Зміст цієї роботи 3 учнями у сучасній загальноосвітній школі-інтернаті органічно пов'язаний з існуючими положеннями “Концепції національного виховання”. Звертання до витоків народного життя, творче використання у практиці скарбів народної мудрості, яка виражена в усній народній творчості і віднесена до духовних цінностей нації, $€$ важливою складовою національного виховання.

Виховання позитивного ставлення до праці шляхом оновлення змісту трудової діяльності в системі позаурочної виховної роботи з учнями пов'язане, також, з формуванням у них активного ставлення до громадського життя i безпосередньою участю в ньому. Визнано, що школа-інтернат, як будь-яка традиційна загальноосвітня школа, має стати центром розвитку в учнів інтелекту та духовності.

На думку багатьох вчених (Г.Я. Майборода, Н.А. Пілієва, Є.Д. Постовойтов, С.Я. Харченко, В.А. Яковлєва та інші), зміна видів діяльності, організаційних форм, перехід від обов'язкових групових до індивідуальних, вільно обраних занять, забезпечують широкий діапазон інтересів, багату духовність учнів $[2 ; 4 ; 5 ; 6]$.

Ми приєднуємось до думки вчених, які визначили основні напрями позаурочної діяльності і віднесли до них:

- освітню позаурочну роботу (проводять учителі-предметники в процесі самопідготовки, консультацій та ін.);

- громадсько-соціальну роботу (мета формування наукового світогляду);

- техніко-трудову роботу (розв'язує завдання політехнічної освіти, трудового навчання і виховання, ознайомлення учнів 3 основами сучасного промислового та сільського господарського виробництва);

- спортивно-туристську діяльність (сприяе вихованню спритності, витривалості юнаків та дівчат, дисциплінованості, почугтя відповідальності, колективізму, гуманізму, самодисципліни);

- природоохоронну та народознавчу діяльність (бесіди, рольові ігри, усні журнали, конкурси, вікторини, трудові операції тощо) [3; 4; 5; 6].

Нами було виявлено, що впливати на успішне виховання учнів шкіл-інтернатів можна ефективно, розвиваючи у них таку якість особистості, як трудова активність. Одночасно, ми звернули увагу на те, що, незважаючи на різноманітний зміст позаурочної виховної роботи з учнями, такі школярі віддають перевагу певному змісту роботи. Зокрема більшість учнів, які мали труднощі у спілкуванні (51,49\%), за результатами опитування, віддають перевагу заняттям у гуртках народної творчості.

Сьогодні, коли серед освітянських завдань $є$ робота 3 відродження художніх, національних ремесел, значну увагу учнів привертають до себе гуртки, в яких школярі працюють 3 природними матеріалами, займаються художніми виробами в техніці “паперопластика", виконують мозаїчні вироби, використовують при виготовленні побутових речей “лоскутову мозаїку”, навчаються петриківському розпису, художній обробці соломки, виготовленню глиняних іграшок тощо. I, як показав наш досвід, 3 особливою захопленістю підлітки (зокрема, учні 3 труднощами у спілкуванні) займаються у гуртку "Українська писанка".

На нашу думку, недоцільно, організуючи діяльність гуртків, порушувати існуючі принципи їх існування: різновіковість членів гуртка; відповідність змісту роботи індивідуальним інтересам учнів; добровільне бажання працювати у гуртку. Старшим учням подобається, якщо молодші із захопленням спостерігають за їх рухами. Одночасно, спостерігається і таке явище: через досить короткий час спостережень у молодших учнів з'являється бажання самостійно виконувати вироби. Саме в такій роботі, досить 


\section{СПЕЦИФІКАВИХОВАННЯПОЗИТИВНОГОСТАВЛЕННЯ ДО ПРАЦІПДЛТТКІВ ЗАГАЛЬНООСВІТНІХ ІНТЕРНАТНИХЗАКЛАДІВ ТА ФОРМИ ІІЇОРГАНІЗАЦІЇ У ПОЗАУРОЧНИЙ ЧАС}

швидко, проявляють власні інтереси школярі 3 труднощами у спілкуванні, оскільки ця “природна уповільненість” поступово зникає, більш того, зовні такі учні змінюються: вони стають радісними, відчувають власну значимість, свої можливості. I, найголовніше, у них 3'являється бажання всіх навчити “своєму ремеслу".

У змісті роботи гуртка "Українська писанка" закладені значні виховні можливості (зокрема, виховання позитивного ставлення до праці), оскільки писанкарство дає змогу керівнику гуртка відроджувати красу народних звичаїв, традицій, обрядів, їх кольоровість та значення у побуті українців. Безумовно, результативність у роботі членів гуртка залежить від попередньої роботи 3 розвитку мотивів діяльності учнів. 3 цією метою керівнику гуртка необхідно починати роботу з казок, легенд, показу яскравих зразків писанок, розповідей про їх символічне значення і таке інше. Програма гуртка "Українська писанка") має забезпечити:

- розвиток пізнавальних і творчих здібностей учнів;

- виховання працелюбності школярів, культури праці, відповідального ставлення до шкільної власності, бережливого ставлення до природи;

- ознайомлення учнів з історією виникнення і розвитку народних ремесел та прикладних мистецтв;

- виховання естетичних почуттів та смаку, розвиток уяви, фантазії і здібностей аналізувати власні дії та здобуті результати;

- формування умінь ручної художньої праці (умінь у виборі сюжету малюнка, кольору та необхідного інструменту для конкретної роботи);

- виховання охайності, наполегливості у досягненні мети, вміння працювати в колективі і самостійно.

Програма діяльності гуртка має врахувати наявність певної матеріально-технічної бази, методичного забезпечення діяльності гуртків.

Завдання на заняттях гуртка розв'язуються, головним чином, у процесі практичного навчання i, насамперед, прийомами особистого показу конкретних операцій керівником гуртка.

Оскільки праця у гуртках $з$ різним змістом роботи здійснюється в позаурочний час i відповідно до індивідуальних інтересів учнів, вони $\epsilon$ найбільш розповсюдженою формою виховної позаурочної робота як у загальноосвітніх школах, так і в школах-інтернатах.

Необхідно зазначити, що в останні роки зміст роботи з українського писанкарства приваблює увагу як керівників гуртків, так і підлітків шкілінтернатів, оскільки цей вид діяльності не потребує особливих фінансових затрат, складної матеріально-технічної бази, дає змогу виготовляти чудові подарунки для рідних та близьких.

Як показала практика, працюючи у гуртку “Українська писанка", підлітки загальноосвітніх інтернатних закладів не відстають у роботі від інших гуртківців. Більше того, якщо вони досягають певних успіхів, і цей успіх визначають інші гуртківці, вони починають випереджати останніх і досить швидко доводять, що спроможні перейти на творчий зміст діяльності.

Ми спостерігали за групою учнів 35 - 9 класів, які були віднесені до окремої групи дітей 3 труднощами у спілкуванні. Вже в період навчання у початковій школі за ними було організовано спостереження. Якщо в $1-2$ класах вони належали до школярів 3 тимчасовою затримкою психічного розвитку (з нашої точки зору помилково), то вже на рівні 3 - 4 класу, за визначеними нами ознаками, їх починають відносити до групи школярів 3 природно уповільненим темпом інтелектуального розвитку. Залучення таких учнів до гурткової художньої діяльності на рівні початкової школи (із складністю завдань відповідно до їх віку) досить швидко і успішно дозволяє перевести їх у групу школярів, розвиток яких відповідає віковим вимогам до нормально розвинутого підлітка. Відчуття школярами власних можливостей і ефективний прояв їх у реальній художній праці, зокрема у гуртковій роботі з писанкарства, сприяє успішній пізнавальній діяльності таких школярів і при вивченні інших навчальних предметів в урочній діяльності.

Найголовнішим мотивом роботи учнів цієї категоріїє прагнення виявити творчі сили, втілити їх у результати своєї діяльності. У них формується позитивне ставлення до своєї праці, з'являється бажання реалізувати у виробах свої оригінальні ідеї і задуми, володіти життєво корисними уміннями і навичками. На цьому етапі навчання (5 - 9 класи) може успішно здійснюватися профорієнтаційна робота 3 такими учнями (підготовка їх до свідомого вибору професії). У гуртковій роботі великого значення починає набувати пошуководослідницька краєзнавча робота.

Керівник гуртка може включити до змісту гурткової роботи пошукові екскурсії, в ході яких передбачається збирання легенд, казок, прислів 'їв, пісень, приказок тощо. Якщо є така можливість, в програмі роботи гуртка можна передбачити зустрічі з майстрами прикладних мистецтв. Найбільш ефективною формою роботи 3 гуртківцями $є$ підготовка їх до проведення виставок учнівських художніх виробів. 


\section{СПЕЦИФІКА ВИХОВАННЯПОЗИТИВНОГОСТАВЛЕННЯ ДОПРАЦІПДЛТТКІВ ЗАГАЛЬНООСВІТНІХ ІНТЕРНАТНИХЗАКЛАДІВ ТА ФОРМИИІЇОРГАНІЗАЦІЇ У ПОЗАУРОЧНИЙ ЧАС}

Незважаючи на реальні успіхи учнів 3 труднощами у спілкуванні і відсутність зовнішніх відмінностей їх від інших учнів, керівнику гуртка потрібно продовжувати роботу з ними, звертаючи особливу увагу на подальший розвиток їх трудової та творчої активності.

Гурткова робота учнів з ручної художньої праці відповідає потребам і можливостям майже всіх учнів, оскільки вони починають розуміти природу краси, сутність народного мистецтва, свою власну приналежність до нього.

Організуючи позакласну та позашкільну гурткову роботу, керівнику гуртка необхідно враховувати профільну спрямованість ручної художньої праці, а також відповідність вимогам програм з трудового навчання. Одним з чинників, що створюють сприятливі умови для творчої діяльності учнів з труднощами у спілкуванні у гуртковій роботі, $є$ зв'язок цих занять із соціально значущими проблемами. Йдеться про реалізацію сучасних вимог щодо відродження національної культури України, зокрема відродження художніх ремесел.

Керівник гуртка для активізації пізнавальної діяльності учнів, які мають труднощі у спілкуванні, повинен розповідати їм різні легенди і пояснювати, чому в різних регіонах України мотиви сюжетів на писанках та їх орнамент відрізняється один від одного. Керівник гуртка звертає увагу на те, що наші предки добре знали техніку розмальовування яєць. 3 найбільшою зацікавленістю учні знайомляться 3 розписом крашанок у рідному регіоні, місті, селі.

Починати знайомство з технікою розпису яєць, доцільно із вивчення учнями видів і призначення інструментів, приладів, їх конструкції. Необхідно пояснити їм залежність майстерності виконання розпису на крашанки від володіння інструментами писанкарства, уміннями вибирати сюжети, символи, що використовуються при розпису (крашанки, дряпанки, мальованки, трав'янки), та умінням підбирати необхідну кольорову гаму.

На першому практичному зайняті з розпису яєць керівник гуртка має ознайомити з прийомами розпису з використанням найпростішої техніки, особливу увагу приділяючи дітям 3 труднощами у спілкуванні. Йдеться про фарбування яйця в один колір і з правилами підготовки яєць до розпису.

Саме на перших заняттях педагог має познайомити цю групу гуртківців 3 технікою виготовлення інструментів для писанкарства. Враховуючи, що складність виготовлення інструментів незначна, учнів необхідно попросити, щоб вони виконали їх самі, або зробили 3 допомогою дорослих. Це необхідно для того, щоб на наступних заняттях учні мали можливість приступити до виконання певних прийомів простого писанкарства. Деякі інструменти (при неумілому їх використанні) можуть травмувати школяра, тому необхідно кожен раз перед початком практичної роботи нагадувати гуртківцям (або запитувати їх) про правила техніки безпеки при виконанні розпису яєць.

При виконанні більш складної технології розпису яєць (наприклад, дряпанка або крашанка), керівнику гуртка доцільно на випереджальному занятті провести творчу роботу з гуртківцями, які мають труднощі у спілкуванні , “фантастичні малюнки для крашанок”. На таких заняттях ці учні мають змогу не лише познайомитися 3 технологіями складання сюжетів малюнків, а й запропонувати свій варіант.

Діалог викладача з учнями, які мають труднощі у спілкуванні, про традиції українського декоративно-прикладного мистецтва має продовжуватись на наступних заняттях i, особливо тоді, коли учні самостійно розробляють орнаментальні мотиви. Перш, ніж починати знайомити гуртківців 3 технікою писанкарства, доцільно розповісти їм історію виникнення писанкарства як мистецтва. Необхідно звернути увагу гуртківців на можливість вивчення сюжетів писанкарства і пошуку їх у самій природі.

У ході видання таких завдань керівник гуртка відзначає особливу зацікавленість таких дітей. Як показала практика, результати їх роботи значно вищі, ніж уінших гуртківців.

Висновки. Дослідивши специфіку виховання позитивного ставлення до праці підлітків загальноосвітніх інтернатних закладів та форми iї організації у позаурочний час, ми дійшли певних висновків, а саме:

1. Зміст трудової діяльності учнів у позаурочний час у сучасних школах-інтернатах повинен бути органічно пов'язаним 3 існуючими положеннями “Концепції національного виховання”.

2. Ми звернули увагу на те, що незважаючи на різноманітний зміст трудової діяльності у позаурочній виховній роботі з учнями, школярі 3 труднощами у спілкуванні віддають перевагу певному змісту роботи. Нами було виявлено, що впливати на успішне виховання позитивного ставлення до праці таких учнів можна ефективно, розвиваючи у них таку якість, як трудова активність.

3. Різноманітність напрямів у змісті трудової діяльності у позаурочній виховній роботі дає можливість, дослідивши інтереси учнів, залучати їх до різних видів діяльності. 
4. Нами було виявлено, що більшість учнів, які мають труднощі у спілкуванні (51,49\%), віддають перевагу заняттям у гуртках народної творчості (зокрема у гуртку "Українська писанка") і не тільки не відстають у роботі від інших гуртківців, a й якщо досягають певних успіхів, починають випереджати інших і досить швидко доводять, що спроможні перейти на творчий зміст діяльності.

\section{ЛІТЕРАТУРА}

1. Аладьин А. А. Психологическая работа с детьми, лишенными родительского попечительства / А.А. Аладьин, И. А. Фурманов, Н. В. Фурманова. - Минск.: Тесей, 1999. - 224 с.

2. Архипова С.П. Соціальна педагогіка / С.П. Архипова,Г.Я. Майборода. Черкаси: ЧДУ, 200 $240 \mathrm{c}$.

3. Канішевська Л. В. Виховання соціальної зрілості старшокласників загальноосвітніх шкілінтернатів у позаурочній діяльності / Канішевська Любов Вікторівна: монографія. - К.: ХмЦНІІ, 2011. -368 c.

4. Кобзар Б.С. Специфіка позаурочної виховної роботи 3 учнями шкіл-інтернатів для дітей сиріт та дітей, які залишилися без піклування батьків/ Б.С. Кобзар, Є.П. Постовойтов. - К.: Стилос, 1997. $-312 \mathrm{c}$

5. Палиева Н. А. Воспитание и личностное развитие детей-сирот в условиях альтернативных форм жизнеустройства: дис. ... д-ра. пед. наук: спец. 13.00.01 “Общая педагогика, история педагогики и образования” / Палиева Надежда Андреевна. - Ставрополь, 2008. - 360 с.

6. Харченко С.Я. Соціалізація дітей та молоді в процесі соціально-педагогічної діяльності: теорія і практика: монографія / С. Я. Харченко. Луганськ: Альма-матер, 2006. - 320 с.

6. Щербаківський В. Українське мистецтво: Вибрані неопубліковані праці / В. Щербаківський; упоряд., вст. ст. В.Ульяновського; додатки
П. Герчанівської, В. Ульяновського. - К.: Либідь, 1995. - 228 с.: іл.

\section{REFERENCES}

1. Aladin, A.A., Furmanov, I. A. \& Furmanova, N.V. (1999). Psikhologicheskaya rabota s detmi, lishennymi roditelskogo popechitelstva [Psychological work withchildren deprived of parental guardianship]. Minsk: Tesey, 224 p. [in Russian].

2. Arkhypova, S.P., \& Maiboroda, H.Ia. (2002). Sotsialna pedahohika [Social pedagogy]. Cherkasy: ChDU, 240 p. [in Ukrainian].

3. Kanishevska, L.V.(2011). Vykhovannia sotsialnoi zrilosti starshoklasnykiv zahalnoosvitnikh shkil internativ u pozaurochnii diialnosti [Upbringing of social maturity of senior pupils of general educational boarding schools in extracurricular activities]. Kyiv: KhmTsNII, 368 p. [in Ukrainian].

4. Kobzar, B.S., \& Postovoytov, E. P. (1997). Spetsifika pozaurochnii diialnosti s uchniyami zahalnoosvitnikh shkil internativ dlay detey-sirot ta detey yaki zalishilis bez pikluvaniya batikiv [Specificity of activities after lessons with students of boarding schools for orphans and children left without parental care]. Kyiv: Stilos, 312 p. [in Ukrainian].

5. Palieva, N. A. (2008). Vospitanie i lichnostnoe razvitie detey-sirot $\mathrm{v}$ usloviyakh alternativnykh form zhizneustroystva [Education and personal developmentof orphans in alternative forms of living arrangements]. Doctor's thesis. Stavropol, 360 p. [in Russian].

6. Kharchenko, S. Ya. (2006). Sotsializatsiia ditei ta molodi v protsesi sotsialno-pedahohichnoi diialnosti: teoriia i praktyka: monohrafiia [Socialization of children and youth in the process of social and pedagogical activity: theory and practice: monograph]. Luhansk: Almamater, 320 p. [in Ukrainian].

7. Shcherbakivskyi, V. (1995). Ukrainske mystetstvo: Vybrani neopublikovani pratsi [Ukrainian Art: Selected Unpublished Works]. Kyiv: Lybid, 228 p. [in Ukrainian].

Стаття надійшла до редакції 07.05.2018

\section{G5808902

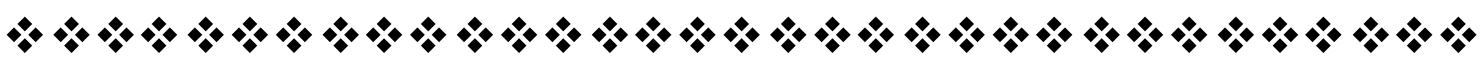

"Людина повинна поважати своє поқлиқання, яқим би воно не було, $i$ підтримувати гідність иъого поқликання, і вимагати від інших поваги до нього, якщо воно того варте".

\section{$\% * \% \%$

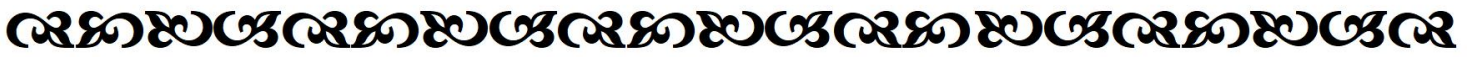

